\title{
Immunoperoxidase techniques: the deleterious effect of sodium azide on the activity of peroxidase conjugates
}

\author{
TC RICHARDSON, DEBORAH V CHAPMAN, EADIE HEYDERMAN \\ From the Department of Histopathology, St Thomas's Hospital Medical School, London SE1 7EH
}

SUMMARY The effect of including sodium azide as a bacteriostatic agent in solutions used to dilute antibodies conjugated with the enzyme horseradish peroxidase was examined. An enzyme-linked immunosorbent assay (ELISA) and an immunohistochemical method were used and both techniques demonstrated an inhibitory effect of sodium azide on the activity of the peroxidase conjugates. It is concluded that the use of sodium azide in solutions used to dilute peroxidase conjugates is to be avoided.

In immunohistochemical studies antibodies conjugated with the enzyme horseradish peroxidase are widely used. The peroxidase enzyme is used to produce localised areas of tissue staining by its ability to precipitate a coloured product when incubated with a suitable substrate, often diaminobenzidine, DAB $\left(3,4,3^{\prime}, 4^{\prime} \text {-tetra-aminobiphenyl hydrochloride }\right)^{1}$. It is common practice to have peroxidase conjugates in solution in a buffer such as phosphate-buffered saline (PBS), to which sodium azide may be added for its bacteriostatic properties. Commercially available preparations of peroxidase conjugates may also include sodium azide as a preservative - for example, DAKO-Immunoglobulins a/s, Copenhagen.

However, there is good evidence that sodium azide is an inhibitor of the peroxidase enzyme. Klapper and Hackett ${ }^{2}$ demonstrated a $57 \%$ inhibition of the oxidation of menadiol by peroxidase by a sodium azide concentration of $4.2 \mathrm{mmol} / \mathrm{l}$ and a $95 \%$ inhibition by a sodium azide concentration of $42.0 \mathrm{mmol} / \mathrm{l}$. Similar evidence was provided by Herzog and Fahimi, ${ }^{3}$ who measured the activity of peroxidase by its ability to oxidise 3,3'diaminobenzidine tetrahydrochloride (DAB) and found that in their system $50 \%$ inhibition of activity could be achieved by a sodium azide concentration of $2 \cdot 0$ $\mathrm{mmol} / \mathrm{l}$ and $95 \%$ inhibition by an azide concentration of $10 \mathrm{mmol} / \mathrm{l}$.

Since sodium azide may be included as a preservative in buffers at concentrations ranging between 3.0 $\mathrm{mmol} / \mathrm{l}(0.02 \%)$ and $15.0 \mathrm{mmol} / \mathrm{l}(0.1 \%)$, it is poss-

Accepted for publication 15 September 1982 ible that peroxidase activity may be significantly inhibited in conjugate preparations. Prior to making bulk dilutions of conjugates and freezing in aliquots that could be subsequently used directly for immunohistochemical staining we examined the effect of azide using both an enzyme linked immunosorbent assay (ELISA) and an immunohistochemical method.

\section{Material and methods}

\section{ELISA STUDY}

The methodology used for the ELISA was based on that described by Voller et al. ${ }^{4}$ Rabbit immunoglobulin (IgG) at a concentration of $5 \mu \mathrm{g} / \mathrm{ml}$ in coating buffer was applied to the wells of microtitre plates (Dynatech Laboratories, Billingshurst, Sussex) and incubated at $4^{\circ} \mathrm{C}$ overnight. After washing the wells three times with azide-free PBS containing $0.05 \%$ Tween $20,0.1 \mathrm{ml}$ of a sheep antirabbit peroxidase conjugate diluted $1 / 64000$ in the same PBS was applied to some of the wells in each plate and incubated at room temperature for two hours. After washing unbound conjugate from the wells using three changes of PBS Tween, $0.1 \mathrm{ml}$ of the peroxidase substrate $o$-phenylenediamine, $(0.4 \mathrm{~g} / \mathrm{l})$ in the presence of hydrogen peroxide $(0.012 \%)$ in citrate buffer $\mathrm{pH} 5.0$ was applied to the wells. A coloured reaction product was generated during the ensuing 30-minute incubation period. The reaction was stopped by the addition of $0.1 \mathrm{ml}$ sulphuric acid $(2.5 \mathrm{~mol} / \mathrm{l})$. The intensity of the colour was measured spectrophotometrically at $492 \mathrm{~nm}$ using a 
Titertek Multiskan spectrophotometer (Flow Laboratories, Irvine, Ayrshire).

This assay was repeated seven days later using further wells on the same microtitre plates. In addition to incubating with freshly diluted conjugate at a similar dilution, replicate conjugates which had been stored frozen for the intervening seven days diluted $1 / 200$ in either $1 \%$ ovalbumin in PBS containing $0.02 \%$ sodium azide, or $1 \%$ ovalbumin in azide-free PBS were also tested. These stored conjugates were further diluted for the purpose of the ELISA to 1/64 000 using azide-free PBS containing 0.05\% Tween 20. Results for the stored conjugates were calculated relative to the freshly diluted conjugate and could be compared with the readings obtained using freshly diluted conjugate on the same microtitre plates from seven days previously.

\section{IMMUNOPEROXIDASE STUDY}

A parallel study was made using an indirect immunohistochemical staining procedure. ${ }^{5}$ First antibodies raised against a variety of different antigens (see Table 2) were incubated on tissue sections for one hour, and after washing the slides appropriate antispecies conjugates were applied and incubated for a further hour. The sections used were approximately $4 \mu \mathrm{m}$ thick, cut from formalin-fixed, paraffin-embedded blocks of tissue. The conjugates had been stored frozen, and diluted ready for use, either in $1 \%$ ovalbumin in azide-free PBS or in $1 \%$ ovalbumin in PBS containing $0.02 \%$ sodium azide. The visible intensity of staining was assessed and is recorded in Table 2 . No negative controls were used in this study as the object was to compare intensity of staining with and without azide, rather than to establish the specificity of the antibodies.

The antibody to carcinoembryonic antigen (CEA) was raised in a rabbit, and affinity-purified using a column containing CEA bound to agarose gel beads which included $\mathrm{N}$-hydroxy succinamide esters (AffiGel 10, BioRad Laboratories, Watford, Herts). The affinity purified antibody was subsequently absorbed with a human spleen extract. This was prepared by homogenising normal spleen in distilled water, adding an equivalent volume of perchloric acid $(1.2 \mathrm{~mol} / \mathrm{l})$ stirring for $30 \mathrm{~min}$. at room temperature and centrifuging $\left(1000 \mathrm{~g}, 4^{\circ} \mathrm{C}, 20 \mathrm{~min}\right)$. The supernatant was extensively dialysed against distilled water and then lyophilised.

\section{Results and discussion}

The differences in spectrophotometer readings के obtained by the ELISA technique are presented in $\overrightarrow{0}$ Table 1 and the immunoperoxidase results in Table 2.

Clearly when a conjugate has been stored frozen in the presence of azide the intensity of colour produced in an ELISA is measurably reduced compared with the same conjugate stored frozen in the absence of azide. This effect is equally well demonstrated when similarly stored conjugate is used in immunohistochemical staining (Table 2) and this is illustrated in the photographs of a squamous carcinoma of the lung stained for carcinoembryonic antigen using conjugate diluted $1 / 200$ in PBS with and without azide (Figure). Non-specific crossreactivity in the affinity purified CEA antiserum had previously been noted in polymorphonuclear cells in sections stained with this antibody. This was due to the presence of non-specific cross-reacting antigen (NCA) in these cells. ${ }^{6}$ This cross-reactivity was removed by the addition of $100 \mathrm{mg}$ perchloric acid $\stackrel{\mathbb{D}}{\triangle}$ extract of human spleen/ml affinity-purified antiserum.

In some cases there were larger differences between the slides treated with conjugates with and without azide. We suspect that where the dilution was optimal a slight difference in conjugate activity would have more effect than when an unnecessarily high concentration of first antibody was used. For example, in this study the antibodies to somatostatin and glucagon were used at concentrations which were too strong to enable a precise assessment of 9 differences in staining intensity to be made. These first antibodies are now used at a greater dilution.

The results obtained using peroxidase conjugated $N$ with antibodies are in agreement with the earlier

Table 1 Effect of sodium azide on the storage of diluted conjugate as measured using an enzyme-linked immunosorbent assay

\begin{tabular}{lll}
\hline $\begin{array}{l}\text { Initial absorbance on first day } \\
\text { (azide-free) }\end{array}$ & $\begin{array}{l}\text { Absorbance after } 7 \text { days stored at }-20^{\circ} \mathrm{C} \\
\text { (azide-free) }\end{array}$ & $\begin{array}{l}\text { Absorbance after } 7 \text { days stored at }-20^{\circ} \mathrm{C} \\
\text { (with } 0.02 \% \text { azide) }\end{array}$ \\
\hline 1.04 & 1.48 & 0.82 \\
1.01 & $1 \cdot 15$ & 0.79 \\
1.04 & 1.18 & 0.90 \\
${ }^{*}$ Means \pm SEM & $1.27 \pm 0.11$ & $0.84 \pm 0.03$ \\
$1.03 \pm 0.01$ & 1.27 \\
\hline
\end{tabular}

*Values are blank corrected spectrophotometer readings from three separate assays. 
Table 2 Effect of sodium azide on the storage of diluted conjugate as assessed using immunoperoxidase staining

\begin{tabular}{|c|c|c|c|}
\hline Tissue & First antibody & Conjugate with azide & Conjugate without azide \\
\hline $\begin{array}{l}\text { Carcinoma of the lung } \\
\text { Carcinoma of the colon } \\
\text { Placenta (1st trimester) } \\
\text { Carcinoma of the thyroid } \\
\text { Carcinoma of the breast } \\
\text { Prostate } \\
\text { Normal pancreas }\end{array}$ & $\begin{array}{l}\text { CEA absorbed with NCA } \\
\text { CEA absorbed with NCA } \\
\alpha \text {-HCG } \\
\text { Calcitonin } \\
\text { Epithelial membrane antigen } \\
\text { Prostatic acid phosphatase } \\
\text { Somatostatin } \\
\text { Glucagon }\end{array}$ & \multicolumn{2}{|c|}{$\begin{array}{lc}\text { Sheep antirabbit conjugate } & (1 / 200) \\
+ & ++ \\
\text { Feeble } & ++ \\
+ & +++ \\
+ & ++++ \\
+ & +++ \\
\text { Feeble } & ++ \\
++ & ++++ \\
+++ & ++++ \\
\text { Donkey antisheep conjugate } & (1 / 100)\end{array}$} \\
\hline Tonsil & $\begin{array}{l}\text { IgA } \\
\text { IgG } \\
\text { IgM }\end{array}$ & $\begin{array}{l}\text { Feeble } \\
++ \\
-\end{array}$ & $\begin{array}{l}+ \\
+ \\
+\end{array}$ \\
\hline Lactating breast & Casein & $\stackrel{+}{\text { Goat antimouse monc }}$ & $\begin{array}{l}++ \\
(1 / 100)\end{array}$ \\
\hline $\begin{array}{l}\text { Carcinoma of the breast } \\
\text { Carcinoma of the cervix } \\
\text { Tonsil }\end{array}$ & $\begin{array}{l}\text { Blood group substance A } \\
\text { Blood group substance B } \\
\text { Ig } \kappa \text { chain } \\
\text { Ig } \lambda \text { chain }\end{array}$ & $\begin{array}{l}\text { Feeble } \\
\text { Feeble } \\
- \\
\text { Feeble }\end{array}$ & $\begin{array}{l}++ \\
+ \\
+ \\
+ \\
+\end{array}$ \\
\hline
\end{tabular}

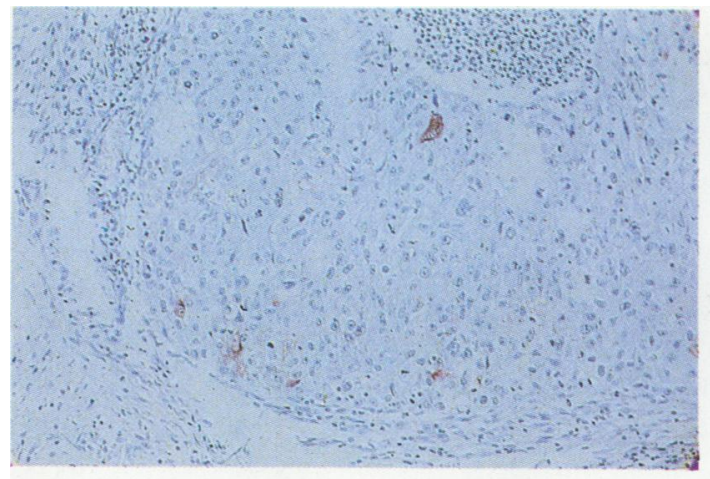

(a)

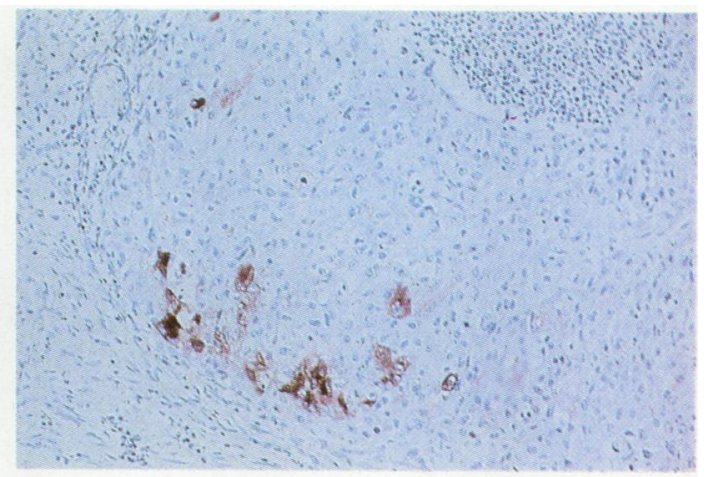

(b)

(a) Section of a squamous carcinoma of the lung stained for CEA by the indirect method with a rabbit anti-CEA first antibody, followed by sheep antirabbit second antibody conjugated with horseradish peroxidase. This conjugate had previously been frozen for seven days in $1 \%$ ovalbumin in PBS containing $0.02 \%$ sodium azide. (b) Serial section of the same tissue, stained using the same procedure, the only difference being that the conjugate had been stored frozen in $1 \%$ ovalbumin in $P B S$ which was azide-free. The reaction product is clearly much stronger and with more positive cells than in (a). The polymorphs in a microabscess (top right) are unstained by this absorbed antiserum.

observations that azide is an inhibitor of the peroxidase enzyme. We now determine the optimum dilution of conjugate on several tissues using a variety of first antibodies and then store suitable aliquots of conjugate at $-20^{\circ} \mathrm{C}$ diluted in $1 \%$ ovalbumin in azide-free PBS: This eliminates one source of experimental variation.

\section{Conclusion}

On the basis of the results from this study it appears that the use of sodium azide as a preservative in diluted preparations of conjugate is to be avoided.
However, peroxidase conjugates have been prepared in this laboratory and stored undiluted at $4^{\circ} \mathrm{C}$ in the presence of $0.1 \%$ azide $^{7}$ for up to 18 months without apparent detriment. Similarly we have not noted any deleterious effect of including azide in preparations of unconjugated antibodies such as the first antibodies used in our staining procedures.

We should like to thank Guildhay Antisera (University of Surrey), Dr Ellison, Dr Leathem, Dr Lennox, Dr Ling, Dr Lippman, Dr Ormerod and Dr Rosen for generous gifts of antisera, and Dr Westwood for CEA. Mr A Bulman raised the antibody to carcinoembryonic antigen. 


\section{References}

' Graham RC, Karnovsky MJ. The early stages of absorption of injected horseradish peroxidase in the proximal tubules of mouse kidney with a structural cytochemistry by a new technique. J Histochem Cytochem 1966;14:291-302.

2 Klapper MH, Hackett DP. The oxidatic activity of horseradish peroxidase I. Oxidation of hydro- and napthoquinones. J Biol Chem 1963;238:3736-42.

${ }^{3}$ Herzog V, Fahimi HD. A new sensitive colorimetric assay for peroxidase using 3,3'-diaminobenzidine as hydrogen donor. Anal Biochem 1973;55:554-62.

${ }^{4}$ Voller A, Bidwell DE, Bartlett A. The enzyme-linked immunosorbent assay (ELISA). A guide with abstracts of microplate applications. 1st ed. Guernsey, GB: Dynatech Europe, 1979.

${ }^{s}$ Heyderman E. Immunoperoxidase technique in pathology: applications, methods and controls. $J$ Clin Pathol 1979;32:971-8.

${ }^{6}$ Heumann D, Canardjis Ph, Carrel S, Mach J-P. Identification of the normal glycoprotein (NGP) crossreacting with CEA as a differentiation antigen of myeloid cells and macrophages. In: Lehmann FG, ed. Carcinoembryonic proteins, chemistry, biology, clinical applications. Amsterdam, New York, Oxford: Elsevier/North Holland Biomedical Press, 1979:2, 3-14.

${ }^{7}$ Heyderman E. Multiple tissue markers in human malignant testicular tumours. In: Carcinoembryonic proteins: recent progress. Scand J Immunol 1978;8:suppl 8, 119-26.

Requests for reprints to: Dr TC Richardson, Department of Histopathology, St Thomas's Hospital Medical School, London SE1 7EH, England. 